\title{
Selvmord blant barn og unge i Norge - noen epidemiologiske utviklingstrekk
}

\author{
Ved Lars M ehlum
}

Store endringer har skjedd i løpet av de senere år i vår holdning til selumordsproblematikken. Det er $i$ dag langt større åpenhet om dette tema enn for bare få år siden. Mange har skjønt at selumord ikke bare angår sosialt marginaliserte grupper eller syke individer, men at det direkte og indirekte kan berøre de fleste av oss.

Ett av de utviklingstrekk som nok har gjort sterkest inntrykk, er økningen av selvmordshyppighet blant unge. I enda sterkere grad enn ellers ved selvmord vil det for de fleste av oss synes meningsløst og uforståelig når et barn eller en ungdom tar sitt eget liv. D erfor har oppslag om slike tilfeller fătt stor oppmerksomhet i massemedia, og denne fokuseringen har ikke alltid vært av det gode. $\mathrm{N} ø$ kterne fremstillinger av selvmordstallenes faktiske størrelsesorden og ikke minst edruelige analyser av hvilke årsaker vi kan anta ligger til grunn for unges selvmord, har vært mangelvare. I denne artikkelen skal vi derfor gi en kort beskrivelse av utviklingen i forekomst av selvmord blant barn og unge i N orge de siste 20-30 år. (D eler av datagrunnlaget for artikkelen er hentet fra M ehlum et al. 1999.)

\section{Norge - en gang et lavhyppighetsland}

I et internasjonalt perspektiv lå selvmordsraten (antall selvmord per 100000 innbyggere per år) i N orge lenge meget lavt. I 1950- og 1960-årene holdt sel vmordsraten seg på mellom

7 og 8, som tilsvarte omtrent 250 selvmord per år for befolkningen som helhet. $V$ åre naboland Sverige og D anmark, og ikke minst Finland, lå langt høyere i rate, og denne forskjellen vakte interesse også utenfor $\mathrm{N}$ orden. $\mathrm{H}$ vordan kunne såvidt like land ha så ulike selvmordsrater? Trolig var det en rekke beskyttende faktorer i familieliv, nærmiljø og forankring i sosiale strukturer som var sterkere virksomme i N orge enn i nabolandene (Juel-N ielsen et al. 1987). Fra slutten av 1960-årene økte imidlertid selvmordsraten kraftig i N orge og var i årene 1986-1990 fordoblet til 16, tilsvarende 650 selvmord per år. Denne fordoblingen gjaldt både menn og kvinner ( $G$ jertsen 1993). H eldigvis flatet økningen i selvmordshyppighet ut fra 1983 til 1988, og og selvmordsraten har etter hvert blitt gradvis redusert. I 1996 (de foreløpig ferskeste tall) ble det således registrert 517 selvmord i landet sett under ett, mens det $\mathrm{i}$ toppåret 1988 ble registrert 708 tilfeller. Totalt var selvmordsraten 30 \% lavere i 1996 sammenliknet med 1988 (Statistisk sentral byrå 1999).

\section{Selvmordsraten blant unge}

For barn og unge (10-24 år) økte selvmordsraten like sterkt som i befolkningen generelt ( $M$ ehlum et al. 1999), fra et gjennomsnitt på 5,4 i årene 1973-74 til 10,3 i årene 1993-94. Det var særlig blant gutter at denne økningen skjedde i det raten øte fra 8,3 til 16,2 etter i mellomtiden å ha nådd en topp i 1991-92 på 20,3 (figur 1).

Blant jenter og unge kvinner har endringene imidlertid vært mer beskjedne, i det selvmordsraten har variert mellom 3 og 5 fra begynnelsen av 70 -tallet til midt på 90 -tallet. A Idersspennet 10-24 år er imidlertid stort. I kke overraskende har endringene i selvmordsraten i undergruppene 10-14, 15-19 og 20-24 vært ulike. U nder alder 15 år har det vært og er stadig svært få selvmord; så få at vi helst ikke regner ut selvmordsrater

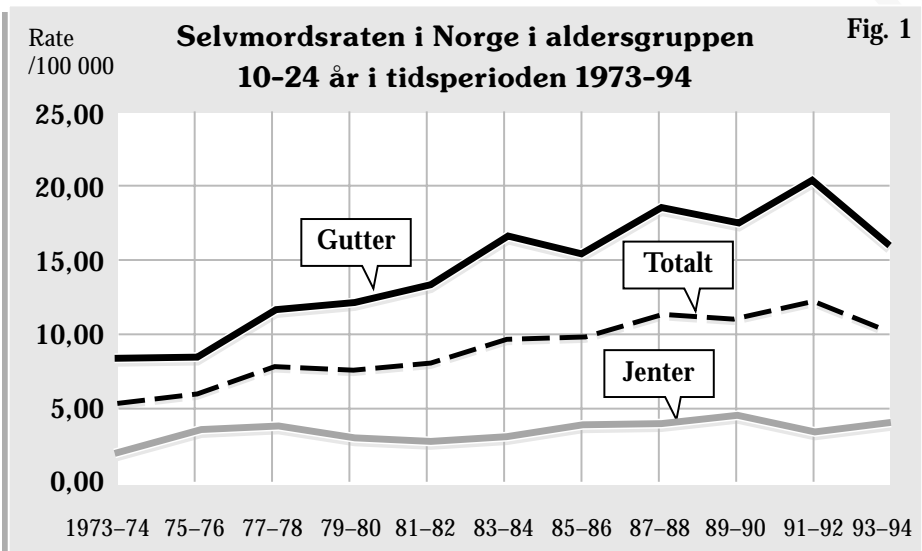

på grunn av den store usikkerheten forbundet med små tall. I landet som helhet har det årlige selvmordstallet variert mellom 0 og 7 blant gutter i denne gruppen, mens det blant jenter har variert mellom $0 \circ \mathrm{g} 2$. Det er vanskelig å trekke sikre slutninger om det har vært noen økning i forekomst av selvmord blant barn under 15 år. Dette står i motsetning til hva som kan synes å være gjengs oppfatning i allmennhet, i massemedia og en dog i mange fagkretser. I manges bevissthet har vi hatt en epidemi av selvmord blant barn, men dette er ikke riktig. For aldersgruppene 15-19 og 20 -24 år dreier det seg imidlertid om langt høyere tall og utviklingen i disse gruppene i tidsperioden 1973-94 er vist i figur 2. Som vi ser, økte selvmordsraten for gutter og unge menn kraftig i begge al dersgrupper. For jenter og unge kvinner er endringene i denne perioden imidlertid beskjedne. Figuren viser også at det fra begynnelsen av 1990tallet har vært en tendens til reduksjon i sel vmordsraten for menn i aldersgruppen 20-24 år. De siste to års tall viser at denne tendensen er ytterligere forsterket. I 1996 ble det således registrert 68 sel vmord blant unge menn under 25 år, en nedgang fra 96 i 1988, 94 i 1991 og 1992 og 75 i 1995. I aldersgruppen 15-19 år fortsatte selvmordsraten å stige til 1995 (opp til 20,3) for så å falle sterkt i 1996 til 12,5. Dette er gledelig, men vi

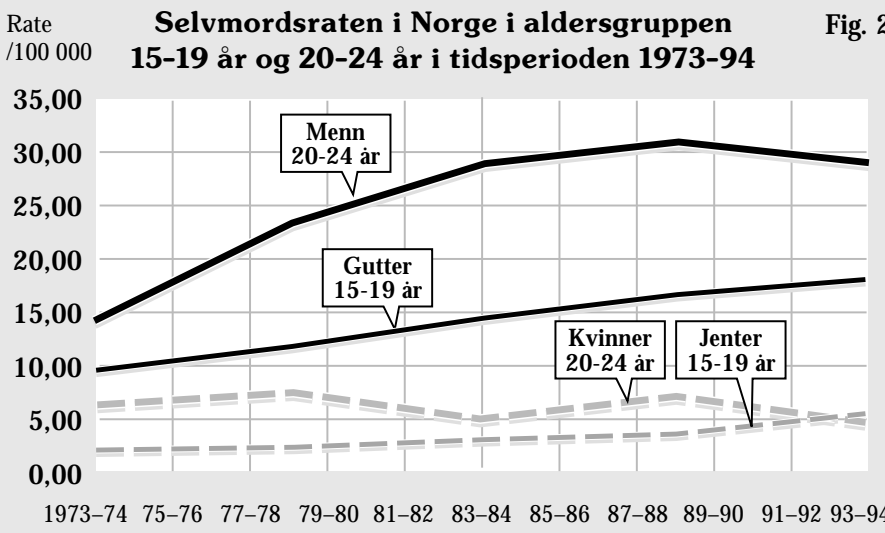


må samtidig huske at det dreier seg om små underliggende tall (28 selvmord i 1995 og 17 selvmord i 1996), og usikkerheten om hvorvidt dette handler om mer enn tilfeldige variasjoner fra ett år til et annet er dermed stor. H vor sprikende tendensene kan bli ved valg av ulike aldersmessige undergrupper $\mathrm{i}$ befolkningen, ser vi f.eks ved å betrakte selvmordsraten blant unge menn i aldersgruppen 20-29 år. H er økte raten fra 22,1 i 1995 til 27,3 i 1996. Det synes alt i alt klokt å mane til en viss forsiktighet i tolkningene av de tilløp til reduksjon i selvmordsraten som vi har sett hos unge i løpet av de senere år. Denne reduksjonen er ikke like entydig som den generelle reduksjon i sel vmordstallene for befolkningen sett under ett.

\section{Selvmord som dødsårsak}

Den totale dødeligheten blant barn og ungdom i alderen 10-24 år avtok fra 58 per 100000 innbyggere i 1973-1974 til 46 i årene 1991-1992. Den viktigste forklaringen på denne gledelige nedgangen er en sterk reduksjon i dødsulykker, samt en mindre nedgang i dødsfall som skyldes sykdommer. I samme periode har imidlertid dødeligheten av selvmord i denne aldersgruppen blitt mer enn doblet, fra 5 per 100000 innbyggere i 1973-1974 til 12 i 1991-1992. Det er unge menn som står for $ø$ øningen. Det er ikke grunnlag for å hevde at selvmordsraten har økt blant kvinner under 25 år i årene 1973 til 1992. H vis den negative utviklingen i selvmordshyppigheten blant menn ikke hadde skjedd, kunne den totale dødeligheten i aldersgruppen 10-24 år vært redusert til omkring 40 per 100000 innbyggere i 1991-1992. Ø kningen i selvmordsdødelighet, samt nedgangen i den totale dødelighet, innebærer at selvmord utgjør en langt høyere andel av alle dødsfall $\mathrm{i}$ aldersgruppen 10-24 år i dag enn tidligere. I 1992 stod selvmord for $26 \%$ av alle dødsfall i aldersgruppen 10-24 år, mens tilsvarende tall i 1973 var $7 \%$. Et interessant utviklingstrekk er at forskjellen mellom unge menns og kvinners selvmordsrater har økt betydelig. I perioden 1973- 1982 hadde menn i alderen 10-24 år 3,6 ganger høyere selvmordshyppighet enn kvinner i tilsvarende aldersgruppe. I neste tiårsperiode var dette tall let økt til 4,6, mens for befolkningen generelt lå forholdstallet stabilt på 2,8 gjennom hele 20-årsperioden.

\section{Geografiske forskjeller}

H vordan har selvmordsraten blant de unge utviklet seg i ulike deler av landet? Fra begynnelsen av 70-tallet og til midten av 90-tallet har det skjedd en økning i de unges selvmordsrater i alle geografiske områder utenfor 0 slofjordområdet. I sistnevnte område nådde man et høyere nivå i selvmordsraten på et mye tidl igere tidspunkt. $\varnothing$ kningen har vært størst i A gder, Trøndelag og N ord-N orge. I 1990-årene er det i disse områdene at selvmordsraten blant unge er høyest. D et er igjen de unge menn som står for økningen. Blant unge kvinner synes de geografiske forskjellene ikke à være til stede, unntatt i 0 slo hvor nivået er høyere enn i resten av landet. I hele perioden 1973-92 er det de unge på Vestlandet som har hatt lavest selvmordsrate. I tillegg til å studere hvordan selvmordsratene varierer i ulike regioner kan det også være interessant å se på mulige forskjeller i disse ratene mellom by og land. Tidligere var selvmord blant unge i $\mathrm{N}$ orge, som i mange andre deler av verden, et utpreget

storbyfenomen. Det synes imidl ertid å ha skjedd en utvikling i retning av at selvmordshyppigheten blant unge i mindre grad samvarierer med kommunens innbyggertall og dens grad av sentralitet (dvs. hvor nær kommunen ligger en større by). På midten av 1970-tallet var selvmordshyppigheten lavest i kommuner med innbyggertall under 50000 og i kommuner med liten grad av sentralitet. Fram mot midten av 90 -tallet har selvmordsraten økt i alle grupper av kommuner (etter innbyggertall), unntatt for kommuner med mellom 50000 og 100000 innbyggere. Det har også vært økning i alle kommunegrupper inndelt etter sentralitetsnivå. I årene 1988-92 er det ingen klare sammenhenger mellom selvmordshyppighet $\mathrm{i}$ aldersgruppen 10-24 år og kommunegruppe (innbyggertall og sentralitetsnivå).

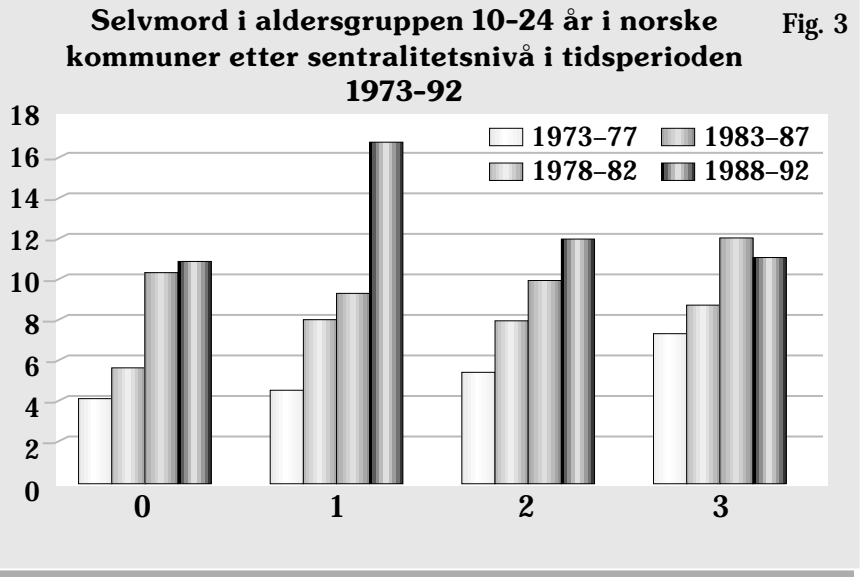

\section{Konklusjon}

Dette er altså de tørre tall når det gjelder utviklingen i omfanget av selvmord blant barn og ungdom. Som vi har sett må vi altså skille klart mellom barn på den ene siden, der det fortsatt er meget sjelden med selvmord, og eldre tenåringer og unge voksne på den annen side, der det har vært en kraftig økning. Dessuten er det klare kjønnsforskjeller. Endelig må vi justere vår oppfatning om selvmord blant unge som et storbyfenomen. I løpet av de siste to år med publiserte selvmordsrater (1995-96) har vi sett en gledelig, men usikker tendens til reduksjon i selvmordsraten hos unge. I løpet av de nærmeste årene blir det spennende å se om denne tendensen vil holde seg eller forsterkes.

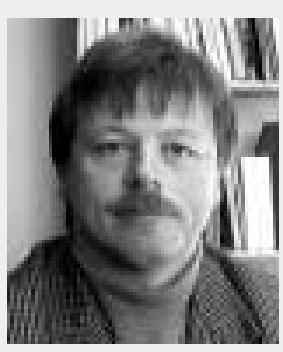

L ars M ehlum er psykiater og professor i suicidologi ved U niv. i 0 slo. $\mathrm{H}$ an er leder for SSFF og er bredt engasjert $\mathrm{i}$ en rekke forsknings- og forebyggingsprosjekter. $\mathrm{H}$ an har publisert flere lærebøker, samt en rekke viten skapelige artikler.

\section{Litteratur}

G jertsen F. Selvmord og ulykker I: Sosialt utsyn. O slo: Statistisk sentralbyrå, 1993: 97-106.

Juel-N ielsen N, R etterstøl N, Bille-Brahe U (eds.):

Suicide in Scandinavia.

A cta Psychiatrica Scan dinavica 1987: Supplementum 336, vol. 76 M ehlum $L, H$ ytten $K$, G jertsen $F$ : Epidemiological trends of youth suicide in N orway. A rchives of Suicide Research 1999; 5: 193-205.

Statistisk sentral byrå.

Dødsårsaksstatistikk for 1996 ble frigitt september 1999,

http://www.ssb.no/dodsarsak/main.htm 